\title{
Cost Targets to Achieve Commercially Viable Thermal Storage in Buildings
}

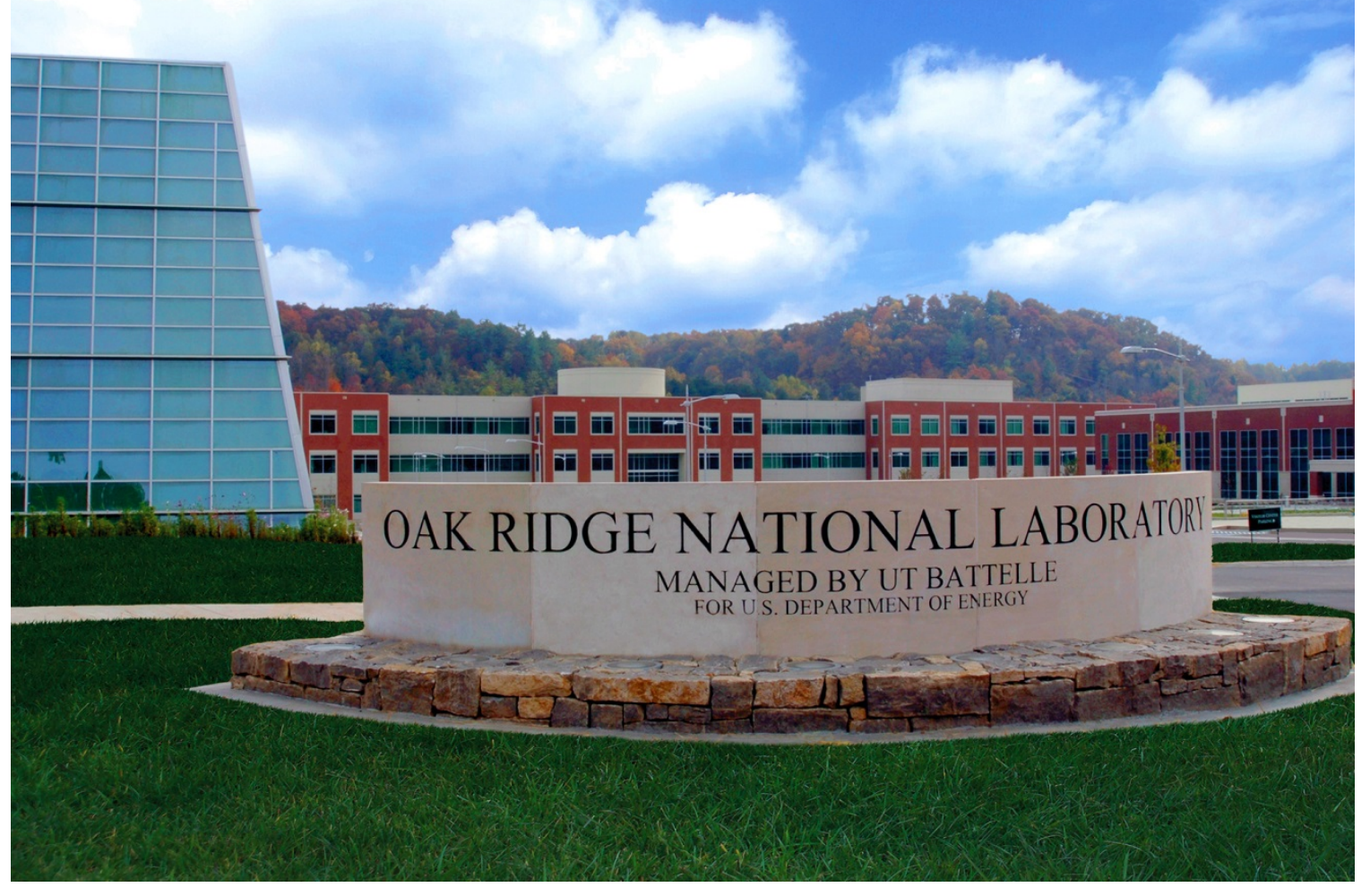

\section{Zhenning Li Juan Catano Drew Welch Kyle Gluesenkamp Rob Comparin \\ Bo Shen}

December 2021 


\title{
DOCUMENT AVAILABILITY
}

Reports produced after January 1, 1996, are generally available free via US Department of Energy (DOE) SciTech Connect.

Website www.osti.gov

Reports produced before January 1, 1996, may be purchased by members of the public from the following source:

\author{
National Technical Information Service \\ 5285 Port Royal Road \\ Springfield, VA 22161 \\ Telephone 703-605-6000 (1-800-553-6847) \\ TDD 703-487-4639 \\ Fax 703-605-6900 \\ E-mail info@ntis.gov \\ Website http://classic.ntis.gov/
}

Reports are available to DOE employees, DOE contractors, Energy Technology Data Exchange representatives, and International Nuclear Information System representatives from the following source:

Office of Scientific and Technical Information

PO Box 62

Oak Ridge, TN 37831

Telephone 865-576-8401

Fax 865-576-5728

E-mail reports@osti.gov

Website https://www.osti.gov/

This report was prepared as an account of work sponsored by an agency of the United States Government. Neither the United States Government nor any agency thereof, nor any of their employees, makes any warranty, express or implied, or assumes any legal liability or responsibility for the accuracy, completeness, or usefulness of any information, apparatus, product, or process disclosed, or represents that its use would not infringe privately owned rights. Reference herein to any specific commercial product, process, or service by trade name, trademark, manufacturer, or otherwise, does not necessarily constitute or imply its endorsement, recommendation, or favoring by the United States Government or any agency thereof. The views and opinions of authors expressed herein do not necessarily state or reflect those of the United States Government or any agency thereof. 
Buildings and Transportation Science Division

\title{
COST TARGETS TO ACHIEVE COMMERCIALLY VIABLE THERMAL STORAGE IN BUILDINGS
}

\author{
Zhenning Li \\ Juan Catano \\ Drew Welch \\ Kyle Gluesenkamp \\ Rob Comparin \\ Bo Shen
}

December 2021

Prepared by

OAK RIDGE NATIONAL LABORATORY

Oak Ridge, TN 37831-6283

managed by

UT-BATTELLE LLC

for the

US DEPARTMENT OF ENERGY

under contract DE-AC05-00OR22725 


\section{CONTENTS}

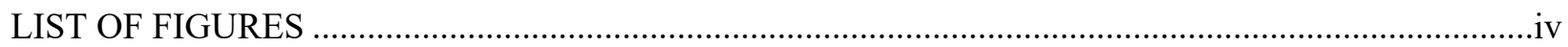

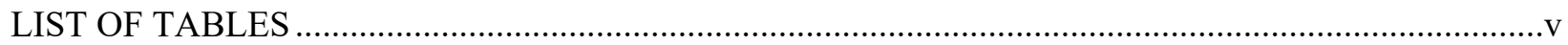

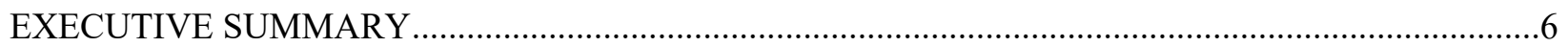

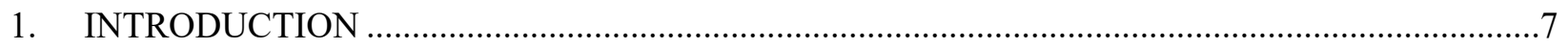

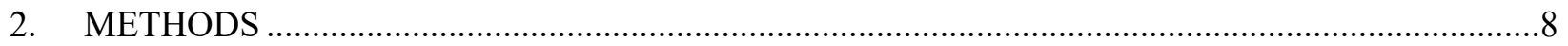

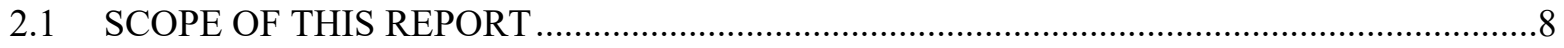

2.2 SIMULATION OF PCM-INTEGRATED HVAC SYSTEM ….....................................

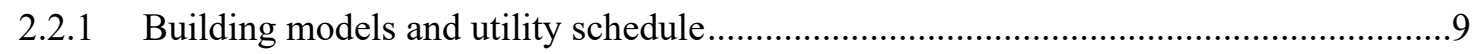

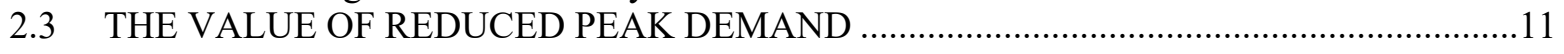

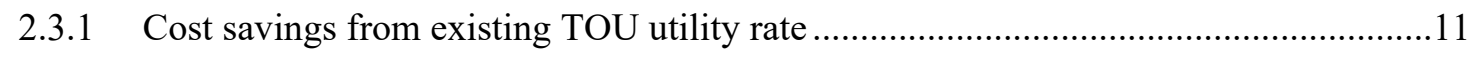

2.3.2 Value from existing DR incentive programs ..........................................................12

2.3.3 Cost savings from capital deferment for new peaking generation...............................13

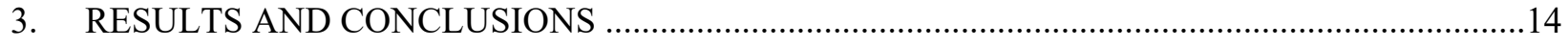

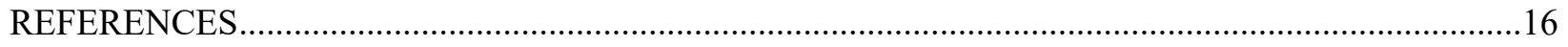




\section{LIST OF FIGURES}

Figure 1. Cost targets to achieve commercially viable TES in Buildings .............................................8

Figure 2. System configuration of a variable-speed DX cooling coil integrated with a PCM

energy storage, water cooling coil, and air-source chiller.

Figure 3. TOU utility rate schedule implemented in the EnergyPlus building simulation........................10

Figure 4. Common utility pricing schemes [2] . ................................................................................

Figure 5. Installed residential system incremental value from TOU and DR programs for TES application in buildings.

Figure 6. Installed system value from peak power plants for TES application in buildings. 


\section{LIST OF TABLES}

Table 1. Cooling seasonal energy simulations in Atlanta, coupled with PCM energy storage. .................11

Table 2. Cooling seasonal energy simulations in Indianapolis, coupled with PCM energy storage. ..........11

Table 3. Cost savings to end-users from TOU utility savings in simulated residential building in

Atlanta and Indianapolis.

Table 4. Cost savings from existing DR incentive programs of California, Texas, and New

England regions.

Table 5. Estimated cost of new peak power plants using different technologies. 


\section{EXECUTIVE SUMMARY}

To mitigate the variation in demand on the electric grid, thermal energy storage (TES) is an alternative to electric batteries or installing new peaking power plants. Stakeholders and policy makers across the United States have expressed interests in promoting TES, as demonstrated by the US Department of Energy's Grid-Interactive Efficient Buildings program and the efforts of various state legislatures. However, the cost value provided by TES are unclear. If reliable cost benefits were determined, stakeholders would have a clearer picture of the financial returns that can be gained from their investment in TES.

In this report, EnergyPlus was used to perform whole-building simulations for two residential buildings in Indianapolis and Atlanta. The HVAC system in both buildings were equipped with phase change material TES. The TES tank was charged in off-peak hours and discharged in peak hours to perform load shifting. First, the economic value implied by existing time-of-use (TOU) rates offered by utility companies was analyzed via whole-building simulation. Second, existing demand reduction (DR) incentives sourced from 3 different electrical grid administrators (i.e., California, Texas, and New England region) were surveyed to determine their implied value. Lastly, the economic value implied by different types of deferred peak power plants were reviewed.

The full value of TES to the entire society consists of value to the utility, OEMs, facility installers, and other stakeholders. This report focuses on the value to the utility with emphasis on the deferred capital of peak power plant. The value from the deferred capital of peak power plant is manifested to the customer in the form of demand reduction program and Time-of-Use utility rate program.

In this report, an initial proxy of the value of TES is made by assuming the deferred capital cost of power plant is the full value to reduce peak demand. Three levels of financial value of TES systems were assessed. Two are currently available to some residential customers: (1) the benefit from TOU pricing alone and (2) the benefit from TOU pricing in combination with DR incentive programs. The third level was computed as the full cost of deferred capital cost of peaking power plants. This represents the potential value that could be gained by the utilities or conceivably be offered to consumers.

The financial benefit for a typical single-family system is demonstrated using three different scenarios. Firstly, based on TOU utility rate savings alone, annual benefits are only $\$ 100$ per residential heat pump system. This is not expected to drive adoption of TES systems. Secondly, the cost savings achieved by combining the TOU utility rate and DR incentive programs are much higher, ranging from $\$ 288$ to $\$ 1,069$ annually per residential heat pump system, depending on the region, with the maximum benefit from TOU and DR was observed under California's DR incentive programs. This level of benefit may drive some TES adoption. Thirdly, the cost savings achieved from deferred capital cost of peaking power plants ranged from $\$ 411$ to $\$ 2,216$. When TES is used as an alternative for photovoltaics power plants, the maximum cost benefit is $\$ 2,216$. When a natural gas power plant is used for peak generation, the maximum cost benefit is $\$ 1,108$. This is greater than the expected cost of implementing TES systems.

The study suggests that the traditional value analysis that focuses on ROI for the building owner significantly undervalues TES technology making economic viability difficult. A more comprehensive value analysis that includes peak demand management and deferred capital for peaking power plants shows that TES should be economically viable for the utility and requires large market penetration and aggregation to fully realize the benefits. Therefore, to facilitate commercialization, new business models are needed that include the broader range of stakeholders and distributes the value of TES proportionally. 


\section{INTRODUCTION}

The aggressive carbon reduction goals set by the United States are increasing the need for thermal energy storage (TES) technologies. TES is an important way to buffer the temporal variations of renewable energy electricity generation. The intermittent availability of renewable sources can result in rapid fluctuations in power supply to the electric grid, and TES can address this issue by storing thermal energy when electricity production exceeds demand and reinjecting energy into the system when supply is short. Since periods of peak demand normally occur in extreme thermal conditions that require large cooling or heating loads on buildings, TES provides an excellent means to buffer imbalances in the supply and demand of electric power. Furthermore, TES can be more cost effective than electrical storage with batteries.

In addition, the retirement of coal-fired power plants throughout the United States could present new opportunities for TES. Although the construction of natural gas power plants will increase initially to achieve compliance with the Clean Power Plan and other emissions standards, over time, the renewable generation will gain an increasingly large share of the generation mix. Thus, load variability and the need for flexible generation will increase the need for TES.

- Reduce emissions of greenhouse gases. TES can help capture excess renewable energy generation from the electrical grid for later use and thus reduce or avoid the curtailment of renewable energy and displace the use of fossil fuels to generate electricity.

- Reduce demand for peak electricity generation. In states where a large portion of electricity is generated using fossil fuel power plants, peak demand is usually met by building more carbonemitting peak power plants because renewable resources are unavailable. TES can be used in place of peak power plants in high-electricity demand hours. It can be an effective alternative to adding generation capacity, thereby reducing demand for peak generation.

- Defer or substitute for an investment in electricity generation. By absorbing and compensating for fluctuating demand on the electrical grid, energy storage can complement existing power plants to meet energy system needs and save the capital costs to build new power plants.

Adding TES to buildings' HVAC systems usually involves integrating the heat pump system with a TES component to shift most of the electricity used for space cooling and/or heating from peak to off-peak periods. Taking space cooling as an example, TES systems produce ice, chilled water, or another solidified phase change material (PCM) during off-peak periods and then discharge the cooling capacity during peak periods. Commonly used PCMs include paraffin wax, ice, and salt hydrates.

Other examples of PCM use in building space-cooling applications include integrating paraffin wax into building walls, which can provide passive cooling by solidifying overnight and then slowly absorbing heat throughout the day [1].

With the development of TES technology, stakeholders are developing new and expanded market opportunities. Combining TES with energy-efficient appliances and demand control can increase endusers' energy savings and participation in demand response programs without reducing comfort. States have developed and promoted various behind-the-meter incentive programs for end-users. The benefits of incentive programs related to TES include: 
- Capitalizing on time-of-use (TOU) rates. With TOU rates, residential building customers can save money if they reduce electricity use during system peak periods. TES can help customers schedule and shift the use of electricity to low-cost periods.

- Reduce demand charges. TES can help customers reduce their peak demand, thereby avoiding large demand charges, which can help commercial and industrial buildings reduce energy costs.

This report analyzes the cost value of deploying TES in buildings. It enumerates the financial benefits of the TOU rate, advanced demand reduction (DR) programs, and deferred peak power plant costs, thereby helping policy makers design new incentive programs that do not undervalue the potential of TES.

\section{METHODS}

\subsection{SCOPE OF THIS REPORT}

The entire cost targets to achieve commercially viable TES in building application are shown in Figure 1.

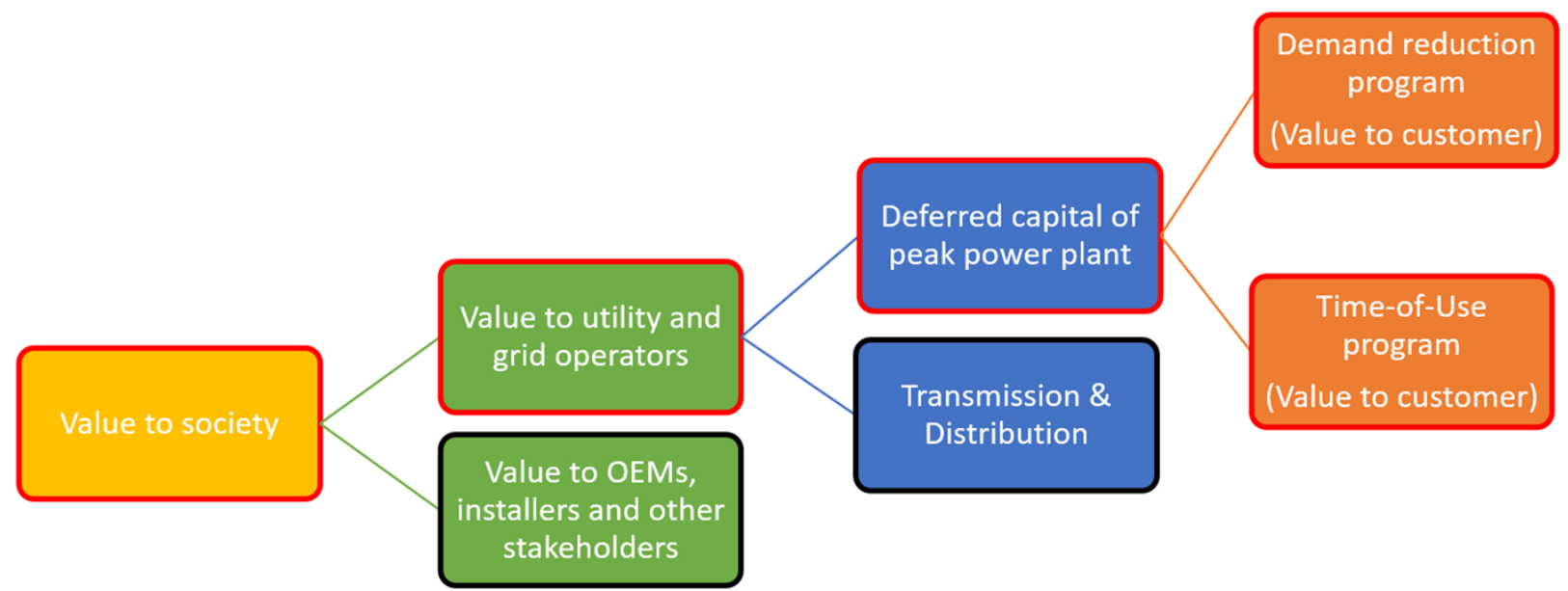

Figure 1. Cost targets to achieve commercially viable TES in Buildings

The value of TES to the entire society consists of value to the utility, OEMs, facility installers, and other stakeholders. This report focuses on the value to the utility with emphasis on the deferred capital of peak power plant. The value to the transmission and distribution is not included in this report. The value from the deferred capital of peak power plant is manifested to the customer in the form of demand reduction program and Time-of-Use utility rate program.

In this report, we make an initial estimate of the value of TES by assuming the deferred capital cost of power plant is the full value to reduce peak demand. Therefore, the cost targets within the scope of this report are highlighted in red rectangular outline as shown in Figure 1. Two methods are used to calculate the benefits from deferred capital cost of peak power plant. The first method calculates the aggregated benefits from demand reduction program and the Time-of-Use program. The second method calculates the installed system value directly by sourcing the capital cost of power plants from different technologies. The results from both methods are presented in this report. 


\subsection{SIMULATION OF PCM-INTEGRATED HVAC SYSTEM}

This study used EnergyPlus to perform whole-building simulations for two typical residential buildings in Indianapolis and Atlanta and assess energy consumption and utility cost of the HVAC systems with PCM energy storage. The PCM drives a chilled water coil and meets the cooling load during peak hours.

For this EnergyPlus simulation, the current EnergyPlus air-source integrated heat pump (IHP) was modified to simulate a multifunctional unit. The IHP object was expanded to include a variable-speed airsource chiller, which charges a PCM storage tank defined in the IHP. Figure 2 shows the TES-integrated HVAC system configuration. It integrates a direct expansion (DX) cooling coil with a supplemental chilled water coil, a PCM storage tank, and an air-source chiller to charge the PCM tank.

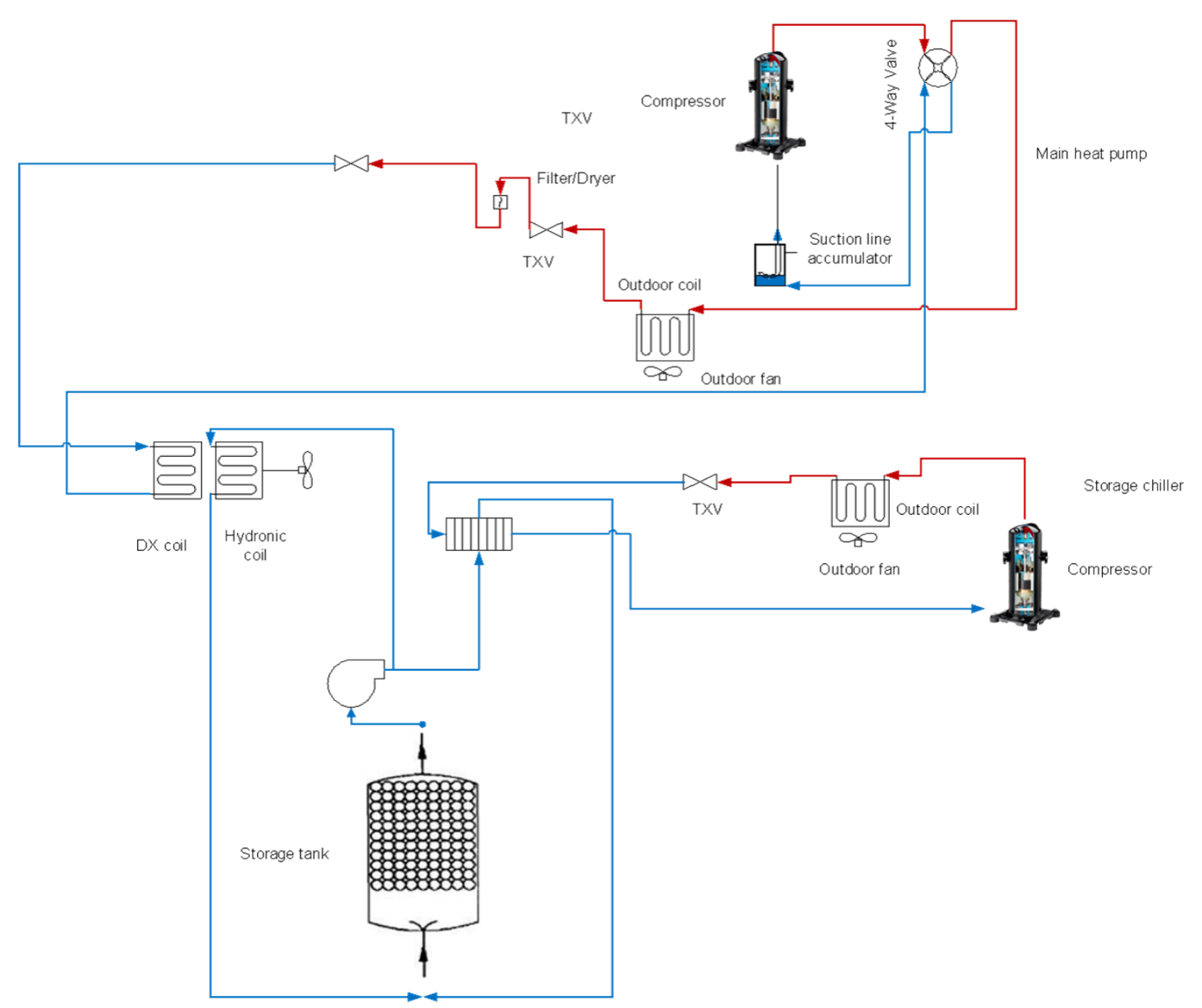

Figure 2. System configuration of a variable-speed DX cooling coil integrated with a PCM energy storage, water cooling coil, and air-source chiller.

\subsubsection{Building models and utility schedule}

To create the building annual energy simulations, a single-family home was chosen from the EnergyPlus library of template buildings. These two houses have $2,500 \mathrm{ft}^{2}$ and a slab foundation. It was built according to the International Energy Conservation Code (IECC) 2006 energy code, and the model is specific to individual climate zones. Two homes based on the EnergyPlus template were simulated. One is located in Atlanta (representing a typical southern US climate), and the other is located in Indianapolis (representing a typical northern US climate). The cooling set point used in the model was $23.3^{\circ} \mathrm{C}\left(73.9^{\circ} \mathrm{F}\right)$ throughout the year. A comparison was conducted between the TES-integrated HVAC system and a baseline air-source heat pump system without TES. 
To assess the utility saving effect of TES, the utility rate schedule was implemented as shown in Figure 3. Since real-time pricing information is not available in Atlanta at the time of this research, we used TOU rates from Chicago to conduct the case study. Figure 3 depicts hourly electricity prices (cents $/ \mathrm{kWh}$ ) in summer. This is the typical pricing pattern in the cooling season based on average pricing data provided by the ComEd Company, the sole electric provider in Chicago and much of Northern Illinois, for January 2016 through December 2019. This grid signal is implemented using the 'Schedule:Compact' feature in EnergyPlus.

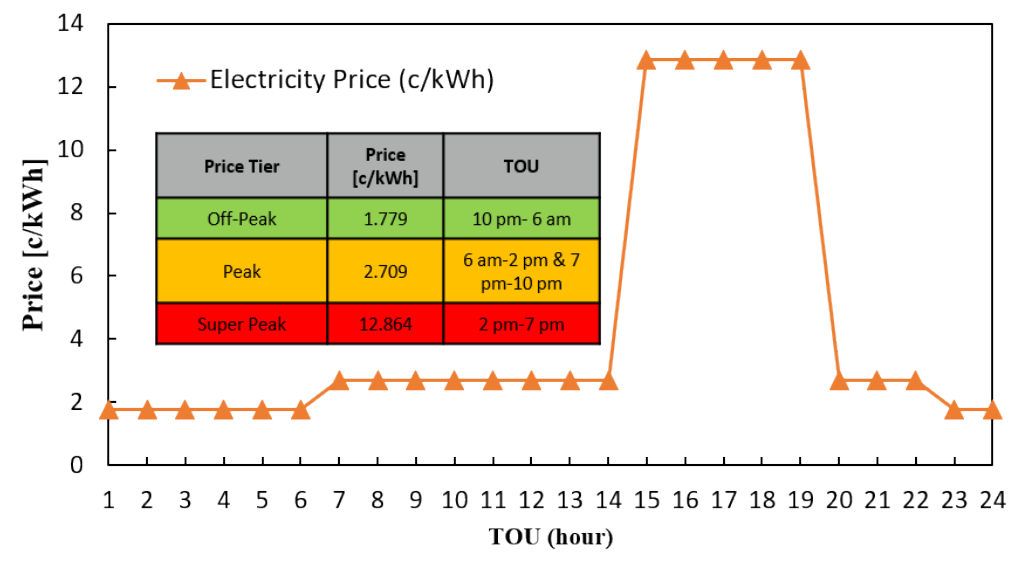

Figure 3. TOU utility rate schedule implemented in the EnergyPlus building simulation.

When the hourly electricity price was above $\$ 0.10 / \mathrm{kWh}$, which covers the period from 12 p.m. to 6 p.m. (peak hours) in summer, the TES regulating strategy was to discharge the PCM tank. During peak hours, the compressor was turned off, whereas the fan was still running the airflow rate corresponding to the high (nominal) compressor speed. The PCM storage tank drove the chilled water coil to provide supplemental cooling. The water coil supply air temperature was controlled at $13.0^{\circ} \mathrm{C}$. This operation strategy is typically referred to as load shedding in demand charge management strategies.

The chiller was auto-sized with the DX cooling coil to maintain a constant ratio between the rated capacities. For charging of the TES system, when the solid PCM fraction was below $90 \%$, the chiller began charging until the solid PCM fraction reached above $99 \%$. The chiller was only allowed to run when the electricity price was below $\$ 0.10 / \mathrm{kWh}$ (i.e., during off-peak hours). This control strategy can be further optimized by including additional parameters such as ambient temperature. To simplify the analysis, the PCM storage tank was assumed to have an exit temperature of $4.5^{\circ} \mathrm{C}$ to the chiller during charging and $10.0^{\circ} \mathrm{C}$ to the water coil during discharging. The PCM had an onset phase change temperature of $5^{\circ} \mathrm{C}$ and termination temperature of $6^{\circ} \mathrm{C}$. The UA, i.e., heat transfer coefficient multiplied with heat transfer area, were auto-sized to satisfy the temperature settings.

Table 1 shows cooling energy simulation results when coupled with PCM storage in Atlanta. During the peak hours, the PCM TES drove the water coil to meet the zone load. The total cooling energy delivered, and the total electricity consumption contains, the energy from both the DX cooling coil and air-source chiller during off-peak hours. Although the energy consumptions with PCM storage for this specific system architecture are higher than the baseline, the total utility costs are lower because the charging operations used low-cost electricity in off-peak hours. 
Table 1. Cooling seasonal energy simulations in Atlanta, coupled with PCM energy storage.

\begin{tabular}{|c|c|c|c|c|c|c|}
\hline & $\begin{array}{c}\text { Total cooling } \\
\text { delivery } \\
\mathbf{( k W h )}\end{array}$ & $\begin{array}{c}\text { Annual unmet } \\
\text { comfort hours } \\
\mathbf{( h r )}\end{array}$ & $\begin{array}{c}\text { Total } \\
\text { electricity } \\
\text { consumption } \\
\mathbf{( k W h )}\end{array}$ & $\begin{array}{c}\text { Total seasonal } \\
\text { coefficient of } \\
\text { performance } \\
\mathbf{( W / W )}\end{array}$ & Cost (\$) & Peak DR (kW) \\
\hline Baseline & $11,069.8$ & 0 & $2,423.0$ & 4.57 & 251.1 & 0 \\
\hline PCM storage & $10,806.7$ & 0 & $2,523.6$ & 4.28 & 175.0 & 2.44 \\
\hline
\end{tabular}

Table 2 presents cooling energy simulation results when coupled with PCM storage in Indianapolis. It indicates similar utility cost saving as the case in Atlanta.

Table 2. Cooling seasonal energy simulations in Indianapolis, coupled with PCM energy storage.

\begin{tabular}{|c|c|c|c|c|c|c|}
\hline & $\begin{array}{c}\text { Total cooling } \\
\text { delivery } \\
\mathbf{( k W h )}\end{array}$ & $\begin{array}{c}\text { Annual unmet } \\
\text { comfort hours } \\
\mathbf{( h r})\end{array}$ & $\begin{array}{c}\text { Total electricity } \\
\text { consumption } \\
\mathbf{( k W h )}\end{array}$ & $\begin{array}{c}\text { Total seasonal } \\
\text { coefficient of } \\
\text { performance } \\
\mathbf{( W / W )}\end{array}$ & Cost (\$) & $\begin{array}{c}\text { Peak DR } \\
\mathbf{( k W )}\end{array}$ \\
\hline Baseline & $8,351.6$ & 0 & $1,797.6$ & 4.66 & 191.7 & 0 \\
\hline PCM storage & $8,374.9$ & 0 & $1,921.9$ & 4.37 & 137.1 & 2.09 \\
\hline
\end{tabular}

\subsection{THE VALUE OF REDUCED PEAK DEMAND}

The goal of this study is to streamline the cost targets to achieve commercially viable thermal storage in buildings. TES systems, unlike adding electricity generation capacity or building new power plants, are traditionally owned, operated, and maintained by the end-user, but different business models could be evaluated where the utility shares some of these costs. End-users and utilities should be encouraged to install TES systems because their overall benefits compare favorably to those from adding generation capacity or implementing demand response programs. The cost savings from reducing peak demand in the following three aspects are addressed in the next subsections:

1. Cost savings from existing TOU rates offered by utility companies to residential customers.

2. Financial value from existing DR incentives offered by utility companies to commercial customers.

3. Cost value from directly from the capital deferment for new peaking generation.

\subsubsection{Cost savings from existing TOU utility rate}

Utility companies use several different pricing schemes for demand response. Among all the schemes shown in Figure 4 (adapted from [2]), TOU pricing is the most common scheme for utility companies. Therefore, this report used TOU utility rate as a representative to demonstrate cost savings. 


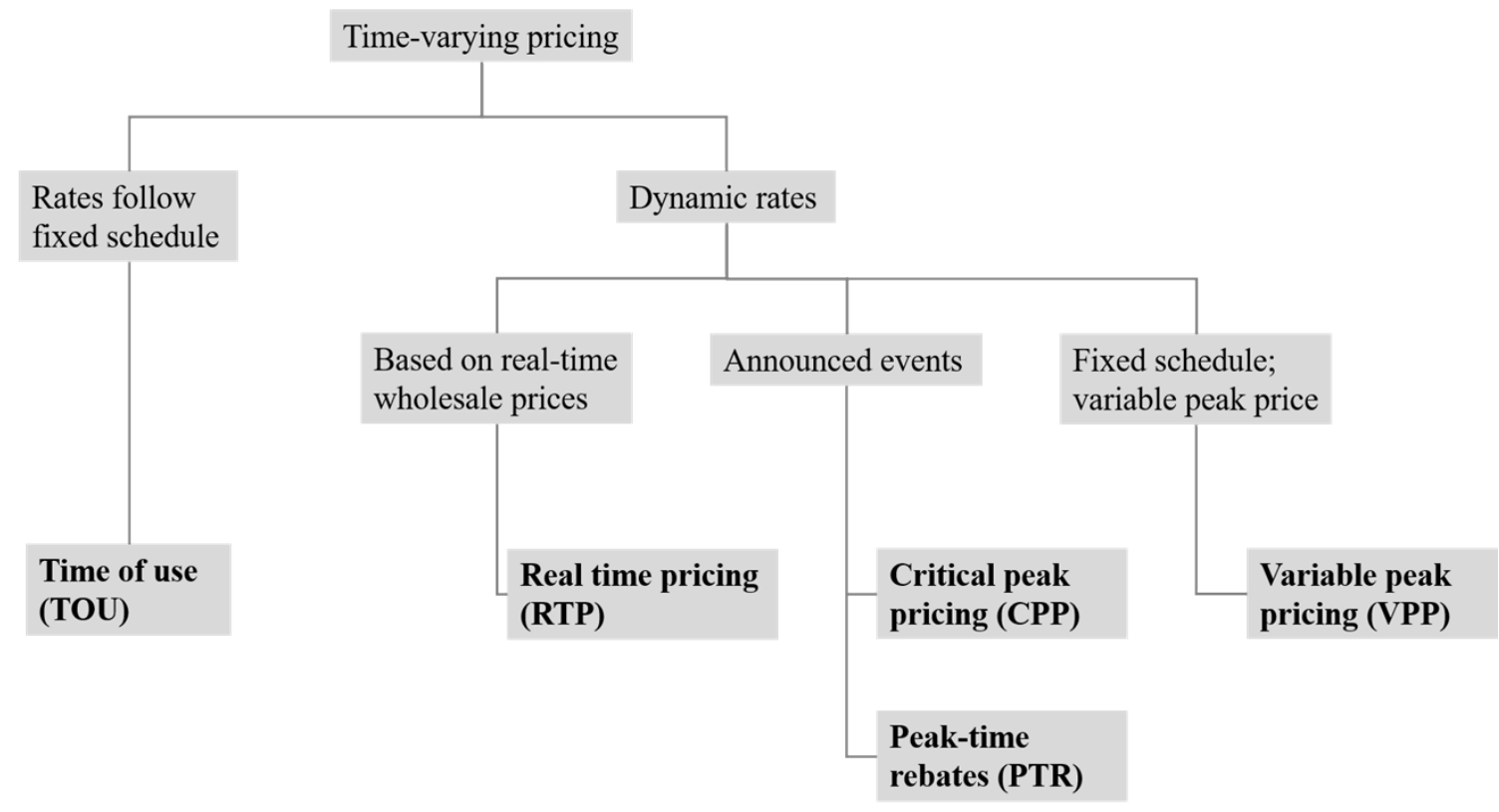

Figure 4. Common utility pricing schemes adapted from [2].

In the United States, residential customers in some states pay a flat rate for electricity, whereas in other states, customers are charged using real-time pricing. TOU utility rates are common for commercial and industrial customers [2], and TOU programs are the most common approach to incentivize demand response. Table 3 lists the cost savings to end-users from TOU pricing in Atlanta and Indianapolis from the EnergyPlus building simulation described above. The annual utility savings are $\$ 76.10$ for the building in Atlanta and $\$ 54.60$ for the building in Indianapolis. The TOU cost savings per unit DR are $\$ 41.10 / \mathrm{kW}$ for Atlanta and $\$ 35.20 / \mathrm{kW}$ for Indianapolis.

Table 3. Cost savings to end-users from TOU utility savings in simulated residential building in Atlanta and Indianapolis.

\begin{tabular}{|c|c|c|c|c|c|}
\hline & $\begin{array}{c}\text { Maximum electrical } \\
\text { power of DR (kW) }\end{array}$ & $\begin{array}{c}\text { Minimum } \\
\text { electrical power } \\
\text { of DR (kW) }\end{array}$ & $\begin{array}{c}\text { Average } \\
\text { electrical power } \\
\text { of DR (kW) }\end{array}$ & $\begin{array}{c}\text { Utility savings } \\
\mathbf{( \$ )}\end{array}$ & $\begin{array}{c}\text { Utility } \\
\text { savings/average } \\
\text { DR (\$/kW) }\end{array}$ \\
\hline Atlanta & 2.44 & 1.25 & 1.85 & 76.10 & 41.10 \\
\hline Indianapolis & 2.09 & 1.00 & 1.55 & 54.60 & 35.20 \\
\hline
\end{tabular}

\subsubsection{Value from existing DR incentive programs}

In addition to TOU programs, utility companies can provide financial incentives to consumers in return for the consumers' ability to control their equipment during peak demand periods. This consumer-based control enables the utility company to reduce the load for that period and avoid using peaking capacity. Additionally, utility companies can alert consumers to opportunities to receive financial compensation for voluntarily reducing their load during peak demand periods. Examples of this type of program include emergency demand response programs, capacity biding programs, and ancillary service programs.

However, the cost savings from existing DR incentive programs are subject to regulations of the electrical grid administrator. These regulations are set by three primary entities: The Federal Energy Regulatory Commission, independent system operators, and public utility commissions. Each of these entities oversees a different area of control. The Federal Energy Regulatory Commission monitors energy transfer 
across state lines, independent system operators monitor transmission and generation in the area in which they operate, and public utility commissions regulate the activities of utilities within their respective states, including capacity acquisition, which can apply to the integration of TES [3].

This survey of DR incentive programs focuses on three regions: California, Texas, and New England. Taking California as an example, Southern California Edison (SCE) offers a one-time incentive of $\$ 300 / \mathrm{kW}$ when joining the company's qualifying DR program. The benefit of joining the SCE DR incentive program ranges from $\$ 50 / \mathrm{kW}$ to $\$ 240 / \mathrm{kW}$ depending on the combinations of enrolled DR programs, which include automated critical peak pricing, real-time pricing, capacity bidding, and demand response auction. After considering various combinations of DR programs, the average cost savings from participating in the SCE DR program is estimated to be $\$ 400 / \mathrm{kW}$. Table 4 shows the estimated cost savings from existing DR incentive programs in California, Texas, and New England.

Table 4. Cost savings from existing DR incentive programs of California, Texas, and New England regions.

\begin{tabular}{|l|c|c|}
\hline \multicolumn{1}{|c|}{ Utility } & Cost savings (\$/kW) & Reference \\
\hline California (SCE) & 400 & {$[4]$} \\
\hline Texas (Austin Energy) & 350 & {$[5]$} \\
\hline New England (Eversource) & 250 & {$[6],[7]$} \\
\hline
\end{tabular}

\subsubsection{Cost savings from capital deferment for new peaking generation}

In 2015, coal-fired power plants accounted for more than $80 \%$ of the nearly $18 \mathrm{GW}$ of retired capacity. The US Energy Information Administration projects that approximately $90 \mathrm{GW}$ of coal-fired capacity and $62 \mathrm{GW}$ of older natural gas and oil capacity could retire by 2040 as a result of the Clean Power Plan unveiled by the Obama administration [8]. The US Environmental Protection Agency and US Energy Information Administration have both projected that renewables and newer natural gas plants will overtake most of the generation share currently held by coal, whereas the generation share held by nuclear power will remain relatively constant.

Application of TES can enable deferring investments in new peak electricity generation since power supply and demand variations can be buffered via storage, which enables a plant's generation capacity to be more closely matched to the average daily power demand as opposed to the peak demand spikes that are present without TES. In this manner, TES can complement existing power plants to meet energy system needs and save the capital costs of building new power plants. Table 5 lists the net annualized life cycle cost of power generation for different types of new power plants over a 30-year lifecycle. These values are obtained from NREL's 2021 Electricity Annual Technology Database, using same assumptions as for the levelized cost of electricity (LCOE) [9]. New power plants using nuclear and biopower have the highest capital cost. Power generation using photovoltaics with electricity storage is based on the rated power and $25 \%$ capacity factor is assumed.

Table 5. Estimated cost of new peak power plants using different technologies.

\begin{tabular}{|c|c|}
\hline Power plant type & $\begin{array}{c}\text { Annualized } \\
\text { cost } \\
\mathbf{( \$ / k W )}\end{array}$ \\
\hline Photovoltaics (with 8-hour electricity storage) & 908 \\
\hline Concentrated solar power & 411 \\
\hline Natural gas & 454 \\
\hline Nuclear & 648 \\
\hline Biopower & 650 \\
\hline
\end{tabular}




\section{RESULTS AND CONCLUSIONS}

The market for energy storage poses many challenges, and the monetization of services provided to the electrical grid by TES can improve its market potential. The economic value from implementation of TOU utility rates, participation in DR incentive programs were aggregated (or "stacked") to see the range of benefits from using TES in buildings. Figure 5 shows the installed system incremental value to building owners and to the utilities from TES implementation in buildings.

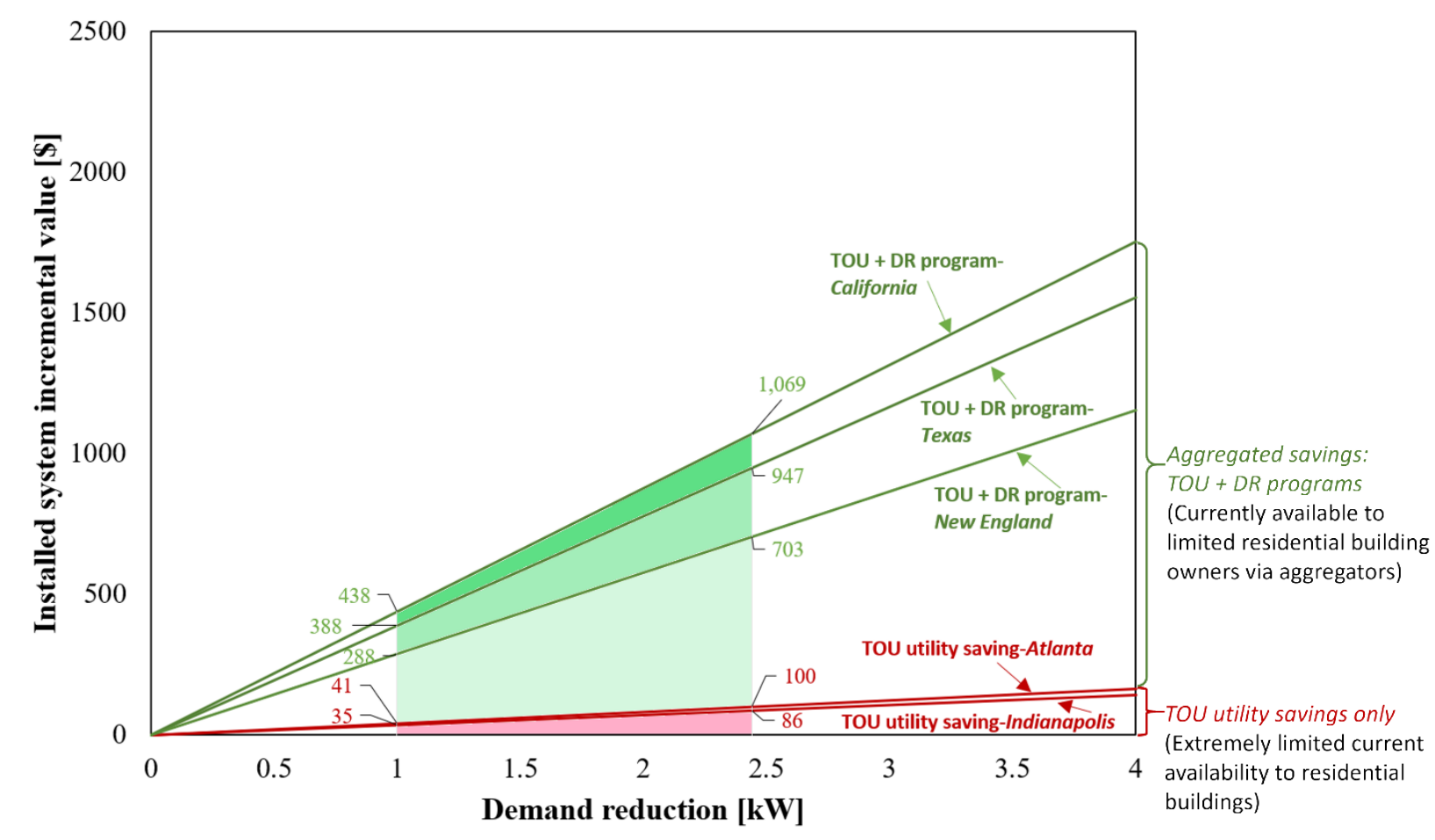

Figure 5. Installed residential system incremental value from TOU and DR programs for TES application in buildings.

The colored region in Figure 5 spans the expected range of demand reduction from a TES system per typical single family residential building. The range of 1 to $2.4 \mathrm{~kW}$ shown here was obtained from the whole-building simulation described in Section 2.1. It will vary by building size, TES system type and size, and climate, but the range of 1 to 2.4 is expected to be roughly representative of US single family residential buildings.

The red area indicates the savings from implementing the TOU utility rate alone, which gives utility savings between $\$ 35$ and $\$ 100$. The green area indicates the aggregated value from implementing the TOU utility rate and DR incentive programs. Depending on the different incentive programs in different regions, the combined cost savings range from $\$ 288$ to $\$ 1,069$. The maximum savings are observed under California's DR incentive program.

The installed system value from deferred capital cost of peak power plant is calculated in Figure 6. 


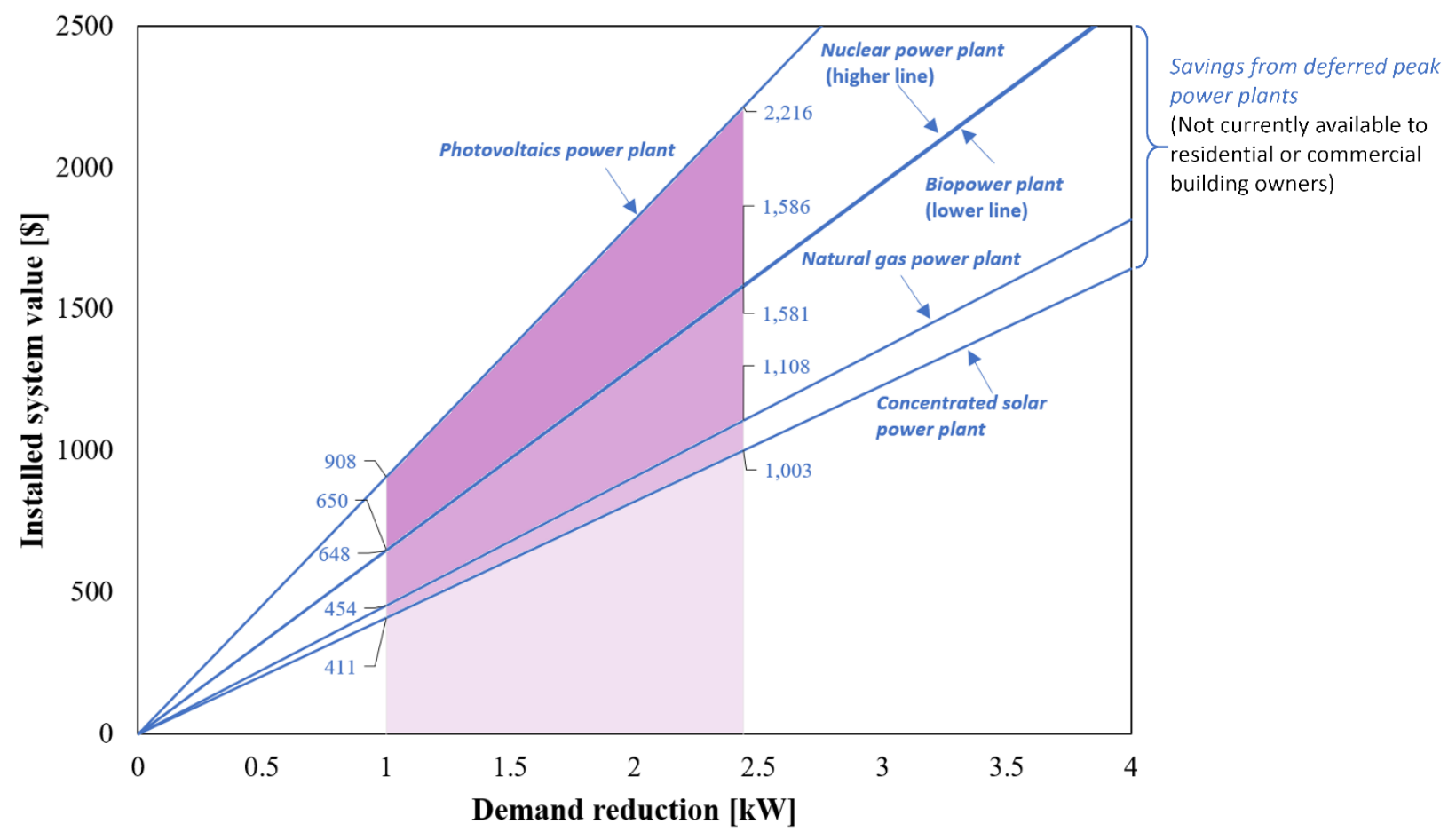

Figure 6. Installed system value from peak power plants for TES application in buildings.

The purple area represents savings from the deferred capital cost of peak power plants from different technologies. As compared to Figure 5, the aggregated value from implementing the TOU utility rate and DR incentive programs is already included in the deferred capital cost of peak power plants, therefore, the cost benefits shown in Figure 6 is larger than those in Figure 5. Depending on different types of power plants, the cost savings range from $\$ 411$ to $\$ 2,216$. If TES is used as an alternative for a photovoltaics based peak power plants, the maximum cost savings are $\$ 2,216$. For the most common peak power plant (i.e., a natural gas power plant), the maximum cost savings are $\$ 1,108$.

Figure 5 and Figure 6 summarizes the results of this study by displaying the benefits of deploying TES in buildings. Figure 5 aggregates the financial benefits of the TOU rate, advanced DR programs, and Figure 6 shows the benefits from deferred peaking power plant costs. This information helps policy makers design new incentive programs that do not undervalue the potential of TES.

Existing incentives offered to residential customers are inadequate to stimulate a market for thermal energy storage. TES technology will be ready for widespread commercialization once a business model is created to link building owners and utilities to the full value of the technology. 


\section{REFERENCES}

1. Sharma, A., V. Tyagi, C. Chen, and D. Buddhi. 2009. "Review on thermal energy storage with phase change materials and applications." Renewable and Sustainable Energy Reviews, vol. 13, pp. 318 345 .

2. Baatz, B. 2017. "Rate Design Matters: The Intersection of Residential Rate Design and Energy Efficiency.” American Council for an Energy-Efficient Economy Report U1703.

3. Akhil, A. A., G. Huff, A. B. Currier, B. C. Kaun, D. M. Rastler, S. B. Chen, A. L. Cotter, D. T. Bradshaw, and W. D. Gauntlett. 2013. "DOE/EPRI 2013 Electricity Storage Handbook in Collaboration with NRECA." Sandia National Laboratories.

4. Southern California Edison. 2019. Automated Demand Response with Express Control Incentives. https://www.sce.com/sites/default/files/inline-files/AutoDR\%20Express\%20Fact\%20Sheet WCAG.pdf

5. Austin Energy. Thermal Energy Storage Rebates \& Incentives. https:/savings.austinenergy.com/rebates/commercial/offerings/cooling-and-heating/thermal-storage

6. Eversource. Optimize Your Energy Use with Storage. https:/www.eversource.com/content/docs/default-source/save-money-energy/storage-demandresponse.pdf?.sfvrsn $=4 \mathrm{f} 39 \mathrm{c} 962 \_2$

7. Eversource. Demand Response For Home Battery Storage. https://www.eversource.com/content/ema-c/residential/save-money-energy/manage-energy-costsusage/demand-response/battery-storage-demand-response

8. US Environmental Protection Agency. 2015. "Fact Sheet: Clean Power Plan - Opportunities for Nuclear Power." 3 December. https://www.epa.gov/cleanpowerplan/fact-sheet-clean-power-planopportunities-nuclearpower

9. Vimmerstedt, L., et al. 2021. "Annual Technology Baseline ATB Cost and Performance Data for Electricity Generation Technologies.” No. 115. National Renewable Energy Laboratory and Oak Ridge National Laboratory. https://atb.nrel.gov/electricity/2021/data 